\title{
Quality Assessment of Improved Sun Dried Ribbon Fish (Trichiurus haumela) by Salt and Turmeric Powder Treatment
}

\author{
Md. Maruf Imtiaz ${ }^{*}$, Syed Ariful Haque ${ }^{2}$, Md. Rajib Sarker ${ }^{3}$, Md. Murad Mufty ${ }^{4}$, \\ Mir Mohammad Ali ${ }^{5}$, Md. Shamim Parvez ${ }^{6}$, Md. Shaheed Reza ${ }^{1}$, Md. Simul Bhuyan ${ }^{7}$ \\ and M. Aminur Rahman ${ }^{6 *}$
}

\begin{abstract}
A study was conducted to formulate a decent quality salted dry ribbon fish (Trichiurus haumela) using solar tent dryer. Sodium salt and turmeric (Curcuma longa) powder were used as ingredients. The quality changes during different storage conditions were examined using organoleptic, biochemical and bacteriological assessment. The contents of moisture, protein, lipid and ash were measured as $17.16-24.90 \%, 50.95-56.47 \%, 4.97-7.12 \%$ and $12.74-17.20 \%$, respectively within $42-46$ hours of drying condition. The bactericidal effects of salt and turmeric on dried fish were studied. The turmeric treatment significantly reduced bacterial growth $(P<0.05)$ than that treated with salt. The lowest bacterial load of $2.1 \times 10^{5} \mathrm{cfu} / \mathrm{g}$ was found in turmeric treated samples, followed by $2.4 \times 10^{5} \mathrm{cfu} / \mathrm{g}$ in salted samples and the highest of $3.0 \times 10^{5} \mathrm{cfu} / \mathrm{g}$ in control samples within seven days' storage condition.
\end{abstract}

Keywords - Trichiurus haumela, Sun drying, Salt, Turmeric Powder, Quality assessment.

\section{INTRODUCTION}

$\mathrm{B}$ ANGLADESH generally known as land of rivers [1] endowed with large areas of open water bodies (rivers, canals, haors, baors and pond areas) [2]. Besides these freshwater bodies, the country possesses a vast seawater area in the south and south eastern region [3]. The varieties and substantial amount of fish and shrimp having a total amount of 30,61,687 MT [2] are caught from these sources, which play a vital role in the economy of this agro-based developing country [4-8]. The people of Bangladesh are habituated and preferred to consume fish in fresh condition. But, it is difficult to reach the fish in fresh state to the consumers all the year round. Moreover, the fish catch abundance in Bangladesh is

\footnotetext{
${ }^{1}$ Department of Fisheries Technology, Bangladesh Agricultural University, Mymensingh-2202, Bangladesh

${ }^{2}$ Department of Fisheries Technology, Sheikh Fajilatunnesa Mujib Fisheries College, Melandah, Jamalpur, Bangladesh

${ }^{3}$ Department of Fisheries Biology and Genetics, Faculty of Fisheries, Patuakhali Science and Technology University, Patuakhali-8602, Bangladesh

${ }^{4}$ Department of Fisheries, Ministry of Fisheries and Livestock, Bangladesh

${ }^{5}$ Department of Aquaculture, Faculty of Fisheries, Patuakhali Science and Technology University, Patuakhali-8602, Bangladesh

${ }^{6}$ Laboratory of Marine Biotechnology, Institute of Bioscience, Universiti Putra Malaysia, 43400 UPM Serdang, Selangor, Malaysia

${ }^{7}$ Institute of Marine Sciences and Fisheries, University of Chittagong, Chittagong, Bangladesh,

*Correspondence: maruf025@gmail.com; aminur1963@gmail.com
}

seasonal. During fish harvesting season, the catch is much higher than the consumers demand. The bulk catch is, therefore, becomes difficult to transport to distance districts and city markets. Hence, there is a necessity to preserve and transport fish in a methodical way to keep the product in good and acceptable condition.

There are different forms of fish processing methods, which have been practicing in Bangladesh. Among them, drying, freezing, salting and smoking is most common. Sun drying is one of the most important economical methods of fish preservation and the product plays an important role particularly for nutrition supply to the underprivileged and economically disadvantaged people. About $20 \%$ of the artisanal catch is sun dried and consumed in the domestic market [9]. However, the organoleptic and physical qualities of most of the old-fashioned sun dried products available in the marketplace are not safe for human consumption [10-13]. Dried fish absorbs moisture from air, resulting in a higher water activity which is advantageous for microbial growth. Insect infestation is also very common [14]. Fat oxidation is a common dispute during storage. Consequently, as much as $25 \%$ of the flesh is lost and the products' price drops to half [15]. In tropical climates, heavy infestation of unsalted dried fish by blow-flies under humid conditions may cause up to $30 \%$ loss of the product [16]. The quantitative losses through spoilage and insect attack on dried fish have been estimated to be $10 \%$ to $35 \%$ in the marine areas $[15,14]$. In Bangladesh, a large quantity of dried fish is spoiled each year due to inappropriate drying, preservation and storage facilities, particularly, during the high yield season [17].

A number of methods are used to improve the quality of traditional sun dried fish. Salting before drying and incorporation of various herbal preservatives have been practiced to improve the quality of dried fish [18, 19]. Salting before drying, is therefore, widely practiced in marine fish drying yards of Cox's Bazar, Moheshkhali, Sonadia and Teknaf area. Other methods, like, use of herbal preservativesturmeric and chili powder are also common in the Cox's Bazar and Sonadia area. These herbal preservatives have a repelling effect to beetles and mites associated dried fish [20]. Hence, there have opportunities to utilize salt and turmeric to produce supreme quality dried fish. The most popular and locally available marine species - ribbon fish was selected for the 
study under different treatment conditions using salt and turmeric. The traditional sun dried technique was used in controlled condition for production of high quality dried products.

\section{MATERIALS AND METHODS}

\section{A. Study area}

The study was conducted in the Cox's Bazar, Bangladesh (Figure 1) from October 2013 to March 2014



Fig. 1. Map of the study area

\section{B. Sample Collection, Processing And Preservation}

The live fresh ribbon fish was purchased from the locals of Cox's Bazar, kept in an insulated box with ice (1:1) and then transported to the Laboratory, Department of Fisheries Technology, Bangladesh Agricultural University, Mymensingh. The average weight of the selected 10 specimens of ribbon fish was $370.60 \mathrm{~g}$ and $295.35 \mathrm{~g}$ before and after gutting, respectively.

After receiving, 30 fresh raw samples were graded according to size, washed with potable tap water and gutted accordingly. The samples were washed again with potable water to remove blood, slime and other undesirable substances. The first ten samples were kept as controlled sample. Another ten sample fishes were soaked for three hours into $20 \%$ salt solution. Then, the remaining ten sample fishes were split longitudinally and turmeric powder was mixed at $1 \%$ ratio with fish. The fishes were divided into three treatments: $\mathrm{T}_{1}$ (controlled), $\mathrm{T}_{2}$ (Salt treated), $\mathrm{T}_{3}$ (Turmeric powder treated).

The fishes under different treatments $\left(T_{1}, T_{2}\right.$ and $\left.T_{3}\right)$ were transferred to the drying facility, made of bamboo splits. The whole structure was covered with small meshed mosquito net to control flies. Some samples of ribbon fish were placed outside the net. The drying time ranges from 72 to 96 hours. The dried fishes were finally graded according to size and quality..

\section{Organoleptic Quality Assessment}

The sample of dried products were taken on a tray to assess the organoleptic characteristics such as color, odor, texture, broken pieces and insect infestation by a four member panels of experts from the Department of Fisheries Technology, Bangladesh Agricultural University, Mymensingh.

\section{Analysis of proximate composition}

Proximate composition analysis of moisture, ash, lipid and crude protein were carried out according to the methods given in AOAC [21] with certain modifications.

\section{Moisture}

The moisture content was estimated by using the following formula:

$$
\begin{gathered}
\text { Moisture }(\%)=\frac{\mathrm{E}}{\mathrm{C}} \times 100 \\
\text { Where, } \mathrm{E}=\text { weight of moisture, } \\
\mathrm{C}=\text { weight of sample. }
\end{gathered}
$$

\section{Ash}

For determination of ash content, the following formula was used:

$$
\begin{aligned}
& \text { Ash Content }(\%)=\frac{\mathrm{E}}{\mathrm{C}} \times 100 \\
& \text { Where, } \mathrm{E}=\text { Weight of ash, } \\
& \mathrm{C}=\text { Weight of sample }
\end{aligned}
$$

\section{Lipid}

The following formula was used for lipid determination:

$$
\text { Lipid Content }(\%)=\frac{\text { Weight of lipid }}{\text { Weight of sample }} \times 100
$$

\section{Crude protein}

The total nitrogen value was obtained by the following formula:

Nitrogen $(\%)=$

ml. acid titrated $\times 0.1 \mathrm{~N}$ acid titrated $\times$ milli equivalent of $\mathrm{N}(0.014)$

$$
\text { Wt. of sample }
$$

The amount of crude protein is then calculated by multiplying the $\%$ total nitrogen with protein conversion factor (6.25).

\section{E. Determination of total volatile base nitrogen (TVB-N)}

Total Volatile Base Nitrogen (TVB-N) was determined according to the methods given in AOAC [21] with certain modifications.

The TVB-N value was calculated by using the following formula:

$$
\operatorname{TVB}-\mathrm{N}(\mathrm{mg} / 100 \mathrm{~g})=\frac{\mathrm{ml} \text { of titrant } \times 0.14 \times 1 \times 100}{\text { Sample wt. }}
$$


TVB-N is used for the determination of the spoilage level during the storage period [22].

\section{F. Microbiological Analysis}

Standard plate count expressed as colony forming units per gram (CFU/g) were determined by utilizing consecutive decimal dilution technique, using pour plate method [23].

\section{Sample preparation and Incubation}

One gram of samples (gills, sediments and intestinal contents) was added with $19 \mathrm{~mL}$ sterile saline peptone water. The mixture was homogenized in a stomacher blender with the diluent for $30-60$ second to prepare $10^{-1}$ solution. $1 \mathrm{ml}$ of the initial suspension (primary dilution) was transferred into a McCartney bottle containing $9.0 \mathrm{ml}$. of sterile peptone salt solution at room temperature and were mixed thoroughly by vortex for 5-10 second, to obtain a $10^{-2}$ dilution. These operations were repeated using the $10^{-2}$ concentration and further dilutions by using at each dilution a new sterile pipette to obtain $10^{-3,} 10^{-4}, 10^{-5}$ and $10^{-6}$ dilutions.

\section{Total bacterial count (TBC)}

One $\mathrm{mL}$ inoculum of each sample was taken by a micropipette from different dilutions. Then, the inoculums were transferred aseptically into the sterile petri dishes with duplicates. The prepared plate count agar was poured into the sample plated and mixed homogenously. The plates were kept in the laboratory room temperature until the agar dried up, after sufficient drying the plates were incubated at $30^{\circ} \mathrm{C}$ for 72 hrs. Plates containing 10-300 colonies were considered to calculate bacterial population, recorded as cfu per unit of sample by using following formula:

$$
\mathrm{N}=\frac{\sum \mathrm{C}}{\mathrm{V}+\left[\mathrm{n}_{1}+\left(0.1 \times \mathrm{n}_{2}\right)\right] \times \mathrm{d}}
$$

Where,

$\sum \mathrm{C}$ is the sum of the colonies counted on all the dishes retained from two successive dilutions, and where at least one contains a minimum of 10 colonies;

$\mathrm{V}$ is the volume of inoculums applied to each dish in milliliters;

$\mathrm{n}_{1}$ is the number of dishes retained at the first dilution;

$\mathrm{n}_{2}$ is the number of dishes retained at the second dilution;

$\mathrm{d}$ is the dilution factor corresponding to the first dilution retained $\{d=1$ when the undiluted liquid product (test sample) is used $\}$.

\section{Statistical Analysis}

One-way analysis of variance (ANOVA) followed by Posthoc LSD test was done to show the significant effects of Turmeric treatment on reduced bacterial growth, using SPSS (Version 22). The data on TBC obtained from dried fish samples were analyzed in completely randomized design (CRD) using computer package MSTST-C [24].

\section{RESULTS}

\section{A. Quality assessment of sun dried ribbon fish}

The organoleptic parameters such as color, odor, texture, insect infestation, presence of broken pieces and overall quality of sun dried ribbon fish ( $T$. haumela) were examined. The color of $T_{1}$ and $T_{2}$ was slightly brown and $T_{3}$ was slightly yellowish. Yellowish color of the dried products indicates that the fish was treated by turmeric powder. Texture was firm and flexible with characteristic odor. Infestation was found after 90 days of storage at $T_{1}$ which were in air exposed condition. The overall qualities of all the three dried fish products were excellent.

\section{B. Proximate composition of dried products}

Moisture content in sun dried ribbon fish ( $T$. haumela) initially after drying was in the range of $17.16-24.90 \%$ with the highest in $\mathrm{T}_{2}$ (salt treated) fish and lowest in $\mathrm{T}_{1}$ (control) (Table 1). Protein ranged from 50.95 to $56.47 \%$ with the lowest and highest value found in $\mathrm{T}_{2}$ (salt treated) ribbon fish and $\mathrm{T}_{1}$ (control) ribbon fish, respectively (Table 1). Lipid and ash contents ranged from $4.97 \%$ to $7.12 \%$ and $12.74 \%$ to $17.20 \%$, respectively.

TABLE I:

PROXIMATE COMPOSITION OF SUN DRIED RIBBON FISH ( $T$. HAUMELA) PRODUCTS AFTER SEVEN DAYS OF DRYING.

\begin{tabular}{lccc}
\hline Compositio & Treatment-1 & Treatment-2 \\
$\mathrm{n}$ & $\left(\mathrm{T}_{1}\right)$ & $\left(\mathrm{T}_{2}\right)$ & $\begin{array}{c}\text { Treatment- } \\
3\left(\mathrm{~T}_{3}\right)\end{array}$ \\
\hline Protein $(\%)$ & $56.32 \pm 0.15$ & $51.05 \pm 0.10$ & $54.96 \pm 0.2$ \\
Lipid $(\%)$ & $5.93 \pm 0.13$ & $5.17 \pm 0.20$ & $6.97 \pm 0.15$ \\
Ash $(\%)$ & $16.19 \pm 0.15$ & $12.91 \pm 0.17$ & $16.95 \pm 0.2$ \\
Moisture & $17.37 \pm 0.21$ & $24.78 \pm 0.12$ & $19.52 \pm 0.1$ \\
\hline
\end{tabular}

On dry weight basis, protein contents of this species were in the range between 61.25 and $72.62 \%$ with the highest value in $\mathrm{T}_{1}$ (controlled). Ash content was in the range from 15.57 to $21.90 \%$.

\section{Food quality}

Generally, food quality of the dried products was analyzed by determining total volatile base nitrogen (TVB-N) [25]. The results of the total volatile base nitrogen (TVB-N) are presented in Table 2. TVB-N values of sun dried ribbon fish were in the range from 17.19 to $20.67 \%$ with the lowest value in $\mathrm{T}_{3}$ (turmeric treated) fish and the highest value in $T_{1}$ (without salt and turmeric) (Table 2). The TVB-N values of all the samples were found to be lower than the recommended value $(100-200 \mathrm{mg} / 100 \mathrm{~g})$ for a variety of salted and dried products [26]. 
TABLE II. TVB-N VALUES OF SUN DRIED RIBBON FISH AFTER 7

DAYS OF DRYING.

\begin{tabular}{lc}
\hline Treatments & TVB-N $(\mathrm{mg} / 100 \mathrm{~g})$ \\
\hline Treatment-1 $\left(\mathrm{T}_{1}\right)$ & $20.35 \pm 0.32$ \\
Treatment-2 $\left(\mathrm{T}_{2}\right)$ & $18.78 \pm 0.25$ \\
Treatment-3 $\left(\mathrm{T}_{3}\right)$ & $17.46 \pm 0.27$ \\
\hline
\end{tabular}

\section{Quantitative Estimation of Bacteria}

Turmeric treatment significantly reduced bacterial growth $(P<0.05)$ than salt where lowest bacterial load was found in turmeric treated samples $\left(2.15 \pm 0.07 \times 10^{5} \mathrm{CFU} / \mathrm{g}\right)$ followed by salt treated samples $\left(2.63 \pm 0.20 \times 10^{5} \mathrm{CFU} / \mathrm{g}\right)$ and the highest value in control samples $\left(3.05 \pm 0.07 \times 10^{5} \mathrm{CFU} / \mathrm{g}\right)$ at day 7 (Table 3).

TABLE III. QUANTITATIVE ESTIMATION OF AEROBIC HETEROTROPHIC BACTERIA OF RIBBON FISH DURING DRYING PERIOD.

\begin{tabular}{cccc}
\hline Days after the treatment & Control (CFU/g) & Salt treatment (CFU/g) & Turmeric treatment (CFU/g) \\
\hline 0 & $3.69 \pm 0.20 \times 10^{5}$ & $3.69 \pm 0.20 \times 10^{5}$ & $3.69 \pm 0.20 \times 10^{5}$ \\
1 & $4.24 \pm 0.15 \times 10^{5}$ & $5.85 \pm 0.07 \times 10^{5}$ & $4.91 \pm 0.20 \times 10^{5}$ \\
3 & $3.51 \pm 0.12 \times 10^{5}$ & $4.21 \pm 0.10 \times 10^{5}$ & $4.23 \pm 0.15 \times 10^{5}$ \\
5 & $3.24 \pm 0.15 \times 10^{5}$ & $3.16 \pm 0.13 \times 10^{5}$ & $2.76 \pm 0.12 \times 10^{5}$ \\
7 & $3.05 \pm 0.07 \times 10^{5}$ & $2.63 \pm 0.20 \times 10^{5}$ & 0.107 \\
LSD at 5\% & 0.202 & 0.117 & $* * 10^{5}$ \\
Level of sig. & $* *$ & $* *$ & \\
\hline
\end{tabular}

$* *=$ Significant at $1 \%$ level of probability

\section{E. Ribbon fish sample (control)}

Average bacterial loads of controlled samples at $\mathrm{D}_{0}, \mathrm{D}_{1}, \mathrm{D}_{3}$, $\mathrm{D}_{5}$ and $\mathrm{D}_{7}$ days were $3.69 \pm 0.20 \times 10^{5} \mathrm{CFU} / \mathrm{g}, 4.24 \pm 0.15 \times 10^{5}$ $\mathrm{CFU} / \mathrm{g}, 3.51 \pm 0.12 \times 10^{5} \mathrm{CFU} / \mathrm{g}, 3.24 \pm 0.15 \times 10^{5} \mathrm{CFU} / \mathrm{g}$ and $3.05 \pm 0.07 \times 10^{5} \mathrm{CFU} / \mathrm{g}$, respectively (Table 3). It was observed that bacterial load was decreasing during the drying period day by day at controlled samples (Fig. 2).



Fig. 2: Bacterial loads of control ribbon fish samples during the drying periods for 7 days.

\section{F. Ribbon fish sample (salt treated)}

Average bacterial loads of salt treated samples at $D_{0}, D_{1}, D_{3}$, $\mathrm{D}_{5}$ and $\mathrm{D}_{7}$ days were $3.69 \pm 0.20 \times 10^{5} \mathrm{CFU} / \mathrm{g}, 5.85 \pm 0.07 \times 10^{5}$ $\mathrm{CFU} / \mathrm{g}, 4.21 \pm 0.10 \times 10^{5} \mathrm{CFU} / \mathrm{g}, 3.16 \pm 0.13 \times 10^{5} \mathrm{CFU} / \mathrm{g}$ and $2.63 \pm 0.20 \times 10^{5} \mathrm{CFU} / \mathrm{g}$, respectively (Table 3 ). It was observed that bacterial load was decreasing during the drying period day by day (Fig. 3).

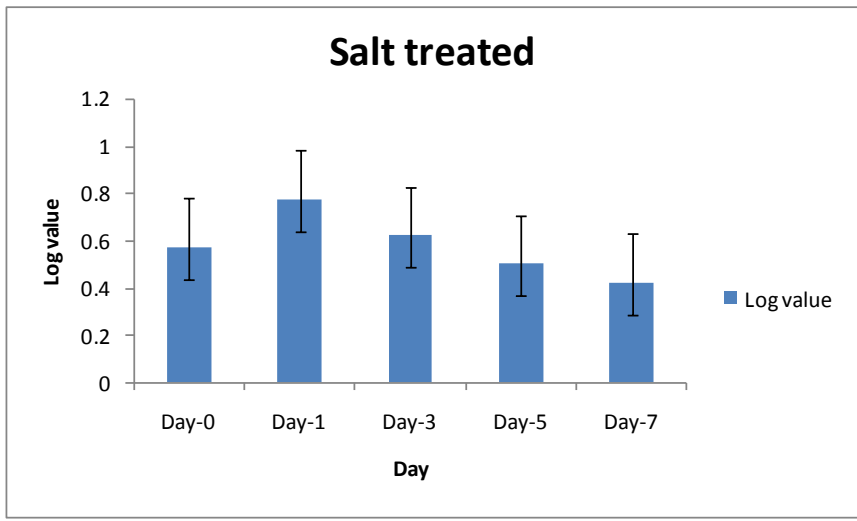

Fig. 3. Bacterial loads of salt treated ribbon fish sample during drying periods for 7 days.

\section{G. Ribbon fish sample (turmeric treated)}

Average bacterial loads of turmeric treated samples at $\mathrm{D}_{0}$, $\mathrm{D}_{1}, \quad \mathrm{D}_{3}, \quad \mathrm{D}_{5}$ and $\mathrm{D}_{7}$ days were $3.69 \pm 0.20 \times 10^{5} \mathrm{CFU} / \mathrm{g}$, $4.91 \pm 0.20 \times 10^{5} \mathrm{CFU} / \mathrm{g}, 4.23 \pm 0.15 \times 10^{5} \mathrm{CFU} / \mathrm{g}, 2.76 \pm 0.12 \times 10^{5}$ $\mathrm{CFU} / \mathrm{g}$ and $2.15 \pm 0.07 \times 10^{5} \mathrm{CFU} / \mathrm{g}$, respectively (Table 3 ). It was observed that bacterial load was decreasing during the drying period day by day (Fig. 4). 




Fig. 4. Bacterial loads of turmeric treated ribbon fish samples during the drying periods for 7 days.

Drying of ribbon fish was completed in seven days. During this period, highest bacterial load was found in controlled ribbon fish at $\mathrm{D}_{7}$ and lowest bacterial load in turmeric treated samples at $\mathrm{D}_{7}$.

\section{DISCUSSION}

The study was conducted to investigate the shelf life of sun dried ribbon fish ( $T$. haumela) under different storage conditions. The study included: drying under controlled condition (improved tent drier), examination of organoleptic parameters, proximate composition analysis, biochemical (TVB-N values) and microbiological analysis. The performances of salt and turmeric treatment against insect infestation and different storage conditions were observed using polyethylene bag, gunny bag and in air exposed condition. The organoleptic characteristics (color, odor, texture, insect infestation, presence of broken pieces) of salt and turmeric treated dried ribbon fish was good except infestation occurred after 90 days in the untreated air exposed dried fish. The salt treated dried ribbon fish was observed to have highest moisture content, irrespective with lowest protein, lipid and ash contents. This finding was similar to the results obtained by Prodhan et al. [27] and Kwon et al. [28]. However, the dry weight basis moisture contents were highest in the controlled ribbon fish, which was more or less similar to that found by Prodhan et al. [27] Afroz et al. [29], who studied the dried spotted Spanish mackerel and dried sword fish, respectively. Mansur et al. [30] showed that moisture content of traditionally dried fishes was ranged from 10.77 to $18.32 \%$ and tent dried fishes from 9.93 to $11.28 \%$, protein content of traditionally dried and tent dried fishes ranged from 51.52$79.29 \%$ and $60.07-72.51 \%$, and fat content ranged from 2.81$11.76 \%$ and $6.43-14.99 \%$, respectively, indicating that the tent dried products were superior to commercially available traditional products. Ahmed et al. [31] mentioned that solar dried fishes contain an augmented percentage (\%) of protein and fat over the traditional sun dried products. Frazier and Westhoff [32] reported that, moisture content below the level of $15 \%$ are responsible for retarding the growth of microbes (yeast, mold and bacteria) in dried products. Sen et al. [33] stated that when water content of fish found below $25 \%$ of wet weight, bacterial action stopped and when the water content further abridged to $15 \%$, mold ceased to breed.

The turmeric treated ribbon fish showed minimum TVB-N values, which were ranged from $17.19 \%$ to $17.73 \%$ compared to salt treated and untreated products. Reza et al. [34] observed that the total TVB-N content were 5.3 to 19.0 $\mathrm{mg} / 100 \mathrm{~g}$ in traditionally sun dried ribbon fish. According to Connell [26], the upper limit of TVB-N is $30 \mathrm{mg} / 100 \mathrm{~g}$, which certify the acceptable level for fin fish dried products. However, the results of this study revealed that TVB-N content in the dry ribbon fishes is very close to the findings of the previous studies and are within the acceptable limit.

Microbiological analysis was conducted during the drying of ribbon fish. The study observed the treatment-wise bacterial growth trend in ribbon fish and the gradual growth of bacteria at controlled condition during drying period. The salt and turmeric reduces the growth of bacteria significantly. In comparison between turmeric and salt treated ribbon fish, turmeric reduces bacterial growth more effectively than salt. The minimum bacterial load $\left(2.15 \pm 0.07 \times 10^{5} \mathrm{CFU} / \mathrm{g}\right)$ was found in turmeric treated samples. Kamaruzzaman [35] and Sultana et al. [36] have studied the microbiological assessment of different fish species from Bangladesh but no such study on the bacterial load of turmeric treated dried fish were found.

\section{CONCLUSION}

This study was performed to produce good quality dried ribbon fish (T. haumela) by combining the effect of both salt and turmeric. During this study, it took around $42-46 \mathrm{~h}$ in the tent dryer covered with mosquito net to complete the drying process. In ribbon fish, the moisture content fell from an initial value of $72 \%$ to a range of $17.16-24.90 \%$ with the highest in salt treated and lowest in control samples. Protein content ranged from 50.95 to $56.47 \%$ with the highest value in control samples and the lowest in salt treated samples. Lipid and ash contents were also ranged from 4.97 to $7.12 \%$ and from 12.74 to $17.20 \%$, respectively. In comparison to salt treated and turmeric treated samples, the study found turmeric reduces bacterial growth more efficiently than salt treated ones. Salt and turmeric treatment protected the dried products against insect infestation during storage, thereby increased their shelf life during storage. From the present findings, it can be concluded that marine dried fish can deliver adequate nutrition and this method might be very useful for the production of noble quality dried fish to meet-up the domestic and international market demand to a greater extent.

\section{REFERENCES}

[1] Chowdhury, Q.M. 2001. Water and Environment, Forum of Environmental Journalist of Bangladesh, ISBN: 983-756-004-8.

[2] DoF (Department of Fisheries). 2011. Fish fortnight publication, Published by the Department of Fisheries, Ministry of Fisheries and Livestock, Dhaka, Bangladesh.

[3] Ali, M. M., Ali, M. L., Islam M. S. and Rahman, M. Z. 2016. Preliminary assessment of heavy metals in water and sediment of Karnaphuli River, Bangladesh. Environmental Nanotechnology, Monitoring and Management, 5: 27-35. 
[4] Ali, M.M., Hossain, M.B., Minar, M.H., Rahman, S. and Islam, M.S. 2014a. Socio-economic aspects of the fishermen of Lohalia river, Bangladesh. Middle-East Journal of Scientific Research, 19 (2): 191195.

[5] Ali, M.M., Hossain, M.B., Rahman, M.A. and Habib, A. 2014b. Diversity of fish fauna in the Chitra river of Southwestern Bangladesh: present status, threats and recommendations for conservation. Asian Journal of Applied Sciences, 7(7): 635-643.

[6] Ali, M.M., Hossain, M.B., Rahman, M. and Rahman, S. 2014c. Post stocking management practices by the pond fish farmers in Barisal District, Bangladesh. Global Veterinaria, 13(2): 196-201.

[7] Ali, M.M., Rahman, M.A., Hossain, M.B. and Rahman, M.Z. 2014d. Aquaculture drugs used for fish and shellfish health management in the Southwestern Bangladesh. Asian Journal of Biological Sciences, 7 (5): 225-232.

[8] Ali, M.M., Hossain, M.B., Masud, M.A. and Alam, M.A.W. 2015. Fish species availability and fishing gears used in the Ramnabad River, Southern Bangladesh. Asian Journal of Agricultural Research, 9(1): 1222

[9] Coulter, J.P. and Disney, J.G. 1987. The handling, processing and marketing of fish in Bangladesh. Overseas Development Natural Resources Institute (ODNRI), Bulletin No. 1.

[10] Kamruzzaman, A.K.M. 1992. Qualitative evaluation of some commercial dried fish products of Bangladesh. M. Sc. Thesis, Department of Fisheries Technology, Bangladesh Agricultural University, Mymensingh, Bangladesh, $37 \mathrm{pp}$.

[11] Khan, M.A.A. 1992. Study on dry fish (marine) with special reference to insect infestation, use of health hazard insecticides and control effect of pirimiphos methyl. M.S. Thesis, Institute of Marine Sciences, University of Chittagong.

[12] Saha, S.C. 1999. Studies on production, marketing and nutritional aspects of traditional dried products of Bangladesh. M.S. Thesis, Department of Fisheries Technology, Faculty of Fisheries, Bangladesh Agricultural University, Mymensingh, Bangladesh, $62 \mathrm{pp}$

[13] Reza, M.S., Bapary M.A.J., Azimuddin, K.M., Nurullah, M. and Kamal, M. 2005. Studies on the traditional drying activities of commercially important marine fishes of Bangladesh. Pakistan Journal of Biological Sciences, 89: 1303-1310.

[14] Ahmed, M., Bhuiyan, A,D, Alam, A.M.S. and Huda, S.M.S. 1978. Radiation and disinfestation studies on sun-dried fish. Proceedings of the $18^{\text {th }}$ session of the Indo-Pacific Fishery Commission, Manila, Philippines, pp. 310-321.

[15] Doe, P.E., Ahmed, M., Muslemuddin, M. and Sachithananthan, K. 1977. A polythene tent drier for improved sun drying of fish. Food Technology in Australia, 29: 437-441.

[16] Wood, C.D. 1981. The prevention of losses in cured fish. FAO Fisheries Technical Paper No. 219, 87 pp.

[17] Neuschler, H. 1998. Fish drying with the solar tunnel dryer type Hohenheim under Bangladesh condition. Final Research Report. Institute of Agricultural Engineering in the tropics and sub-tropics, Hohenheim University, Stuttgart, Germany.

[18] Lithi, U.J., Hassan, M.N., Hossain, M.M. and Alam, A.K.M.N. 2012. Suitability of herbal pesticides, turmeric and neem, in repelling dry fish insect Necrobia sp. adult. Journal of Bangladesh Agricultural University, 10(2): 339-348.

[19] Akter, T., Ahmed, A.T.A., Khaleque, M.A. and Begum, M. 2013. Effect of drying on quality of tengra (Mystus vittatus) treated with turmeric and salt. Unique Research Journal of Biological Science, 1: 1-5.

[20] Nowsad, A.K.M.A. 2005. Low-cost Fish Processing in Costal Bangladesh. BGD/97/017, Field Doc: 5/2005. FAO, 88 pp.

[21] AOAC (Association of Official Analytical Chemists). 1980. In: Horwitz, N. (Ed.), Official Methods of Analysis, Association of Official Analytical Chemists, 13th Edition, Washington, D.C., USA, 957 pp.

[22] Cobb, B.F. and Venderzont, G. 1975. Development of a chemical test for shrimp quality. Journal of Food Science, 40: 121-124.

[23] ISO 4833:2003. Microbiology of food and animal feeding stuffsHorizontal method for the enumeration of microorganisms-Colonycount technique at $30^{\circ} \mathrm{C}$.

[24] Freed, R.D. 1992. MSTAT-C. Crop and Soil Science Department, Michigan State University, USA.

[25] Islam, M.T., Kamal, M., Islam, M.N., Neazuddin, M. and Mehbub, M.F. 2006. Organoleptic, biochemical and bacteriological aspects of the low- cost tunnel dried fish products. Bangladesh Journal of Fisheries Research, 10: 175-183.

[26] Connell, J.J. 1995. Control of Fish Quality. Fourth edition published by Fishing News Books, a division of Blackwell Scientific Ltd.

[27] Prodhan, S., Kamrujjaman, M., Hossain, M.A. and Islam, M.S. 2010. A comparative study of effects of radiation $(1 \mathrm{kgy})$ and heat treatment $\left(50^{\circ} \mathrm{C}\right)$ on the bio-chemical and mineral contents of dried spotted Spanish mackerel, Scomberomorus guttatus (Bloch and Schneider, 1801). Bangladesh Journal of Zoology, 38(2): 205-212.

[28] Kwon, J.H., Byun, M.W., Warrier, S.B., Kamat, A.S., Alur, M.D. and Nair, P.M. 1993. Quality changes in irradiated and non-irradiated boiled-dried anchovies after inter country transportation and storage at 25 C. Journal of Food Science and Technology, 30(4): 250-260.

[29] Afroz, T., Nabi, M.R., Shaheen, T., Mamun, A.A. and Hossain, M. 1995. Effects of radiation on chemical composition of dried sword fish, Lepturacanthus savala (Cuvier) during storage at room temperature. Bangladesh Journal of Life Sciences, 7(1-2): 89-94.

[30] Mansur, M.A., Islam, M.N., Chacraborty, S.C. and Chaity, F.A. 1990. A comparative study in the traditional and solar tent dried fish. Bangladesh Journal of Fisheries, 13: 33-39.

[31] Ahmed, A.T.A., Mustafa, G. and Rahman, H.N. 1979. Solar drying of silver jewfish, Johnius algenraws (Houttuyn) in polythene tent dryer. Journal of Biological Sciences, 8 (1): 23-30.

[32] Frazier, W.C. and Westhoff, D.C. 1978. Microorganisms important in food microbiology. Cited in Food Microbiology, Third Edition, McGraw-Hill Book Company, New York, USA, 539 pp.

[33] Sen, D.P., Anandaswamy, B. Iyenger N.V.R. and Lahiry, N.L. 1961. Studies on the storage characteristics and packaging of the sun dried salted mackeral. Food Science, 10(5): 148-156.

[34] Reza, M.S., Bapary, M.A.J., Islam, M.N. and Kamal, M. 2008. Optimization of marine fish drying using solar tunnel dryer. Journal of Food Processing and Preservation, 33: 47-59.

[35] Kamruzzaman, A.K.M. 1992. Qualitative evaluation of some commercial dried fish products of Bangladesh. M.Sc. Thesis, Department of Fisheries Technology, Bangladesh Agricultural University, Mymensingh, Bangladesh, 37 pp.

[36] Sultana, N. and Hossain, M.T. 2010. Microbial quality of dried fish of different areas Chittagong and Mymensingh districts of Bangladesh. International Journal of Bioresearch. 2(8): 1-5. 